\title{
Landscape stewardship for a German UNESCO Biosphere Reserve: a network approach to establishing stewardship governance
}

\author{
Klara J. Winkler ${ }^{1,2}$ and Jennifer Hauck ${ }^{3}$
}

\begin{abstract}
The German East Frisian Peninsula is a multiuse area with land demands by stakeholders with different goals, including agriculture, tourism, nature conservation, and housing. The state administration is in the process of extending the transition zone of the existing UNESCO Biosphere Reserve Wadden Sea of Lower Saxony onto the peninsula. In this paper, we explore the characteristics of the existing societal structures in order to identify both potential catalysts and possible pitfalls for the establishment of landscape stewardship as a governance approach for the transition zone. Landscape stewardship is a place-based concept integrating participation and relational values into environmental governance. We use Net-Map, a participatory social network method, to explore the types of relationships and influence that stakeholders perceive and the extent to which the landscape could serve as an operational unit for governance. We find various stakeholder groups on the peninsula, with agricultural groups and municipalities perceived as having the most influence and being the best connected. We identify five types of relationships (formal, institutionalized, informal, sporadic, none) and four kinds of influence (legal, political, land, financial). Additionally, the landscape has cultural importance that could foster stewardship. The Biosphere Reserve administration may function as a catalyst for establishing landscape stewardship on the East Frisian Peninsula by bringing stakeholders together and highlighting the shared goal of preserving the landscape for the future.
\end{abstract}

Key Words: governance; Lower Saxony; SNA; Wadden Sea

\section{INTRODUCTION}

UNESCO Biosphere Reserves function as model areas for the sustainable development of humans and nature (Ruoss 2013). A large part of their area is typically composed of a "transition zone" that focuses on sustainable economic and social development (Ishwaran et al. 2008). The United Nations Educational, Scientific and Cultural Organization (UNESCO) confers the Biosphere Reserve title with the aim to preserve both ecological and cultural values in areas with special relationships between people and landscapes (UNESCO 1996). As part of their recognition of these relationships, biosphere reserves should aim for participatory, multistakeholder governance (Price 2017, Reed et al. 2017). Biosphere reserves are, as such, suitable platforms to confront complex land-use challenges because different opinions can be considered and compromises can be found, as opposed to many conservation areas where one objective - nature protection -is typically the dominant management priority (Schultz et al. 2015, Plummer et al. 2017). Bennett et al. (2018) suggest that biosphere reserves are areas where efforts to establish landscape stewardship may be particularly likely to succeed.

The state administration of the Biosphere Reserve Wadden Sea of Lower Saxony in northwest Germany is attempting to extend its transition zone onto the land of the East Frisian Peninsula (EFP). Currently, only $0.8 \%$ of the area is designated as a transition zone. This is contrary to UNESCO guidelines, which anticipate that each biosphere reserve will have a designated transition zone covering more than $50 \%$ of the total area of the biosphere reserve (UNESCO 1996, Bundesamt für Naturschutz (BfN) 2017). Like many landscapes, the EFP faces many demands on its land from different stakeholders, including agriculture, tourism, nature conservation, and renewable energies (Karrasch et al. 2014, 2017, Reise 2015). In addition, the EFP has a strong local identity originating from its history of land reclamations, its unique local language, and its tradition of independence from any German monarchy (Behre and van Lengen 1995). The extension of the transition zone presents an opportunity for a governance approach that acknowledges the existing societal structure on the EFP, which consists of diverse stakeholder groups, each with its own local identity, knowledge, and values, who partly already act and interact in other governance contexts.

In this paper, we explore the potential of landscape stewardship for the governance of the extended Biosphere Reserve Wadden Sea of Lower Saxony. We use a participatory social-network analysis (SNA) method to learn from 20 local stakeholders about relationships and influences among stakeholders on the EFP. We find five types of relationships and four kinds of influence. Additionally, we find a strong local identity that could help foster stewardship. Lastly, we discuss challenges of engaging stakeholders across scales and of integrating preexisting societal structures when creating new governance structures.

\section{LANDSCAPE STEWARDSHIP}

Stewardship, in an environmental context, originates from a personal connection to nature and is often based on moral virtues (Welchman 2012, Chan et al. 2016). It is increasingly used in social-ecological systems research (Peçanha Enqvist et al. 2018) with different framings, e.g., ecosystem stewardship (Folke et al. 2009, Chapin et al. 2010, 2015), landscape stewardship (Plieninger and Bieling 2017), or environmental stewardship (Chan et al. 2016, Bennett et al. 2018).

Landscape stewardship is "a place-based, landscape-scale expression of broader ecosystem stewardship" (Plieninger and Bieling 2017:5) that is a "strategy to respond to and shape socialecological systems under conditions of uncertainty and change to sustain the supply and opportunities for use of ecosystem services to support human well-being" (Chapin et al. 2010:241). Specifying that landscape stewardship is "place-based" underlines 
the context-specificity of stewardship due to people's place attachment (Chapin et al. 2012, Plieninger et al. 2015, Chan et al. 2016). Stewardship is an action-oriented and intersectoral concept in which stakeholders from various backgrounds can improve the resilience of a social-ecological system with their activities (Romolini et al. 2013, Palomo et al. 2016).

We focus on existing societal structures for implementing landscape stewardship, which is a research gap in the landscape stewardship literature (Buck et al. 2017). So far, research has focused on describing existing stewardship networks but has neglected exploring preexisting structures (Bennett et al. 2018, Peçanha Enqvist et al. 2018). Plieninger and Bieling (2017) identify three relevant aspects for landscape stewardship: (1) stewards; (2) intersectoral coordination and activities; and (3) the landscape as an operational unit.

\section{Stewards}

Identifying stakeholders is important in order to understand who could potentially act as a steward (Alexander and Armitage 2015, Alexander et al. 2016). Individuals, groups, or networks can function as stewards if they adopt a virtuous behavior toward nature (Welchman 2012). Stewards "protect, care for or responsibly use the environment in pursuit of environmental and/ or social outcomes in diverse social-ecological contexts" (Bennett et al. 2018:599). In landscape stewardship, typical stakeholders can include local communities (e.g., local people, residents), producers (e.g., farmers), nonstate organizations (e.g., community-based organizations, nongovernmental organizations), research institutions, governments, and the private sector (Buck et al. 2017).

\section{Intersectoral coordination and activities}

Landscape stewardship should foster intersectoral coordination and activities, and thus, relationships between stakeholders are of interest (Romolini et al. 2013, Palomo et al. 2016, Plieninger and Bieling 2017). However, stewardship does not emerge from a void: stakeholders hold different levels of influence and might already be connected (Torfing 2005). Influence is an important aspect in the governance of natural systems because it promotes a power shift from central authorities to a collective of stakeholders (Raik et al. 2008, Fabinyi et al. 2014, Berbés-Blázquez et al. 2016, Reed et al. 2017). A potential pitfall is when one stakeholder (group) dominates a process due to their influence (Bixler et al. 2016a). If stakeholders feel equally influential, and the state acts as an enabler and coordinator, a participatory governance process can be an alternative to a top-down approach (Paavola et al. 2009, Newig et al. 2010). Influence has not been the focus of stewardship research, despite the fact that the success of stewardship governance has been found to be related to influence (e.g., access rights, the power to make decisions) (Felipe-Lucia et al. 2015, Plieninger et al. 2015, Cockburn et al. 2018). A closer look at relationships between stakeholders, different types of relationships, and stakeholders' perception of the distribution of influence, using a stakeholder analysis method, can help to identify potential catalysts for effective governance (Enqvist et al. 2014, Alexander and Armitage 2015, Romolini et al. 2016).

\section{Operational unit}

Landscapes are social-ecological units that include material and social-cultural dimensions (Angelstam et al. 2013, Raymond et al. 2016). Using them as an operational unit allows governance that pursues social-ecological objectives like the biosphere reserve concept demands (Chapin 2017, Conrad 2017, Plieninger and Bieling 2017). The boundaries of the physical, sociocultural, and institutional elements of landscapes are often overlapping and not clearly defined (Epstein et al. 2015, Pittman et al. 2015, Treml et al. 2015). Much of the environmental stewardship literature has focused on more clearly defined spatial units such as watersheds (Fischer 2015, Scharin et al. 2016) or urban areas (Svendsen and Campbell 2008, Romolini et al. 2013, Enqvist et al. 2014). The ambiguous boundaries of landscapes can be a challenge when developing governance approaches (Conrad 2017).

\section{STUDY AREA}

The EFP refers to the coastal area between Dollart Bay and Jade Bay on the German North Sea coast (Fig. 1). To the north, the Wadden Sea-the largest intertidal coastal ecosystem in the world (Common Wadden Sea Secretariat n.d.) - delimits the EFP. For centuries, humans have created a unique cultural and ecological landscape through land reclamation (Brunckhorst et al. 1995). There is a strong local identity due to the long historical relationship between people and the landscape, in addition to their own language (Plattdeutsch) and the history of the area, which long remained an independent jurisdiction, separate from any German monarchy (Reise 2014).

Fig. 1. Map of the East Frisian Peninsula in northwest Germany.

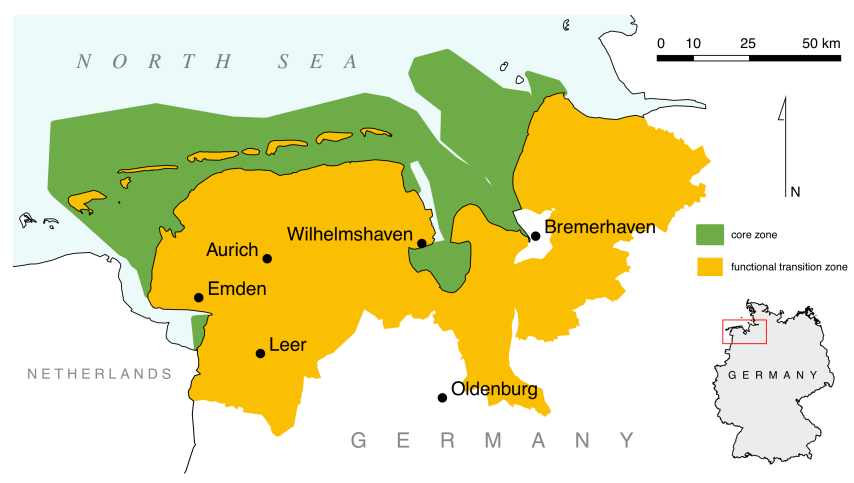

The characteristic landscape of the EFP spans political, historical, and sectoral boundaries. The low lands are characterized by drainage ditches, dikes to protect the land from the sea, and open grassland used for agricultural (dairy) and energy production (Reise 2014, Cebrián-Piqueras et al. 2017, Karrasch et al. 2017, Levers et al. 2018). Over two-thirds of the land is designated agricultural land, contributing $2.0 \%$ to the gross value added and employing about $3.4 \%$ of the labor force (county and sector-specific data in Appendix 2; Landesamt für Statistik Niedersachsen (LSN) 2018). In the last decade, the EFP has experienced a massive increase in renewable energy, mainly wind energy, with the result that people now call it an "energy landscape" rather than an "agricultural landscape" (Gailing and Leibenath 2013). Every year, an estimated ten million migratory birds use the Wadden Sea and the connecting lands for staging, wintering, or molting (UNESCO n.d., Laursen et al. 2009). 
Mainly for this reason, about $42.0 \%$ of the area is protected under the European Natura 2000 legislation (Niedersächsischer Landesbetrieb für Wasserwirtschaft, Küsten- und Naturschutz (NLWKN) n.d., European Environment Agency (EEA) 2017). Lastly, tourism plays an important economic role, with the unique landscape and the coast attracting millions of tourists every year (LSN 2018).

Numerous policies with different objectives, rules, and spatial boundaries overlap on the EFP. Apart from state, national, and European environmental and agrarian policies affecting the landscape, additional objectives and spatial entities exist due to a set of (protection) titles, including National Park, UNESCO World Heritage Site, and UNESCO Biosphere Reserve. In combination with other entities, such as local action groups for rural development (LEADER) or tourism associations, this creates a quagmire of overlapping institutions affecting areas with different spatial extents on the EFP.

In recent years, the state administration has worked to expand the transition zone of the biosphere reserve from the sea onto the land of the EFP in order to fulfill the UNESCO objectives for biosphere reserves. The transition zone should cover more than $50 \%$ of the area, but so far, only $0.8 \%$ of the biosphere reserve is designated as a transition zone (UNESCO 1996, BfN 2017). Additionally, the governance should be participatory, with a diverse set of involved stakeholders (UNESCO 1996). The Biosphere Reserve Administration is part of the state-level National Park administration, and there is currently no participatory approach in place. In order to comply with the objectives, the state has initiated an expansion process (BUND 2015, Nationalpark Wattenmeer 2014, 2017), but faces indifference and opposition, mainly from farmers who fear new restrictions around land use and production (Glückselig 2016, Hanz 2018). The goal of the state administration is to incorporate into the Bioreserve municipalities along the coast as well as the East Frisian islands, into the Biosphere Reserve. The hope is that the strong local identity and the century-old human-nature relationship will serve as fertile ground for the establishment of participatory governance of an extended transition zone.

\section{METHODS}

We conducted a social network analysis (SNA) to understand stakeholders (nodes) and their characteristics and connections (edges) (Alexander and Armitage 2015). A better understanding of how stakeholders are connected can be used for the establishment and governance of natural resources fitting the institutional reality of social systems (Reed et al. 2009, Alexander and Armitage 2015). The network structure can help to identify pitfalls and catalysts of a network in a resource use and environmental governance context (Belaire et al. 2011, Prell et al. 2011, Mills et al. 2014, Alexander et al. 2016). Furthermore, SNA can reveal which stakeholder perspectives build the basis for decision making (Spangenberg et al. 2015).

We used Net-Map, a participatory social network method (Schiffer and Hauck 2010, Hauck et al. 2015). As a semistructured method, it helps explore complex governance situations, including social, economic, and political aspects (Bennett 2016). It reveals the knowledge stakeholders hold on formal, but especially on informal, institutions. This can help to create governance arrangements that are compatible with existing institutions to avoid perverse outcomes such as parallel structures or opposition (Bodin and Prell 2011, Tengö et al. 2014).

During the Net-Map process, the interviewer and interviewees (i. e., stakeholders) jointly create a social network in three steps, based on the interviewees' experience and knowledge (Schiffer and Hauck 2010): (1) interviewees name stakeholders in their networks; (2) they explain the relationships between the named stakeholders; and (3) they express how they perceive the influence of the named stakeholders. The focus on the interviewees' perception gives them the opportunity to voice and explain their perceptions and thus, learn about informal institutions (Schiffer and Hauck 2010, Hauck et al. 2015).

\section{Methodological approach}

\section{Data collection}

We conducted 20 interviews between August 2016 and November 2016 that took between 45 minutes and 2 hours. We started our interviews with representatives of agriculture as agriculture is the most visible land use on the EFP. Based on their networks, we contacted other stakeholder groups that were named during the interviews (snowball sampling). We tried to get stakeholders with a fair spatial and sectoral distribution over the whole EFP. We interviewed representatives of various state and nonstate organizations (for a list and description of the interviewees, see Appendix 1). Seventeen of the 20 interviews were recorded with the interviewees' permission; the other three were documented with interviewer notes. All the interviewees live on the EFP and thus, have a personal and a professional relationship to the landscape. We contacted various organizations to represent the energy and the local business sector but were unable to get a positive response.

We followed the three steps of the Net-Map process and asked the interviewees to give reasons for their choices during each step. During step two, interviewees were free to name any relationship they were aware of and found important to mention. To simplify the comparability of step three between the interviews, we gave each interviewee 10 playing bricks to assign how they perceived the influence levels to the named stakeholders (i.e., more bricks equals more perceived influence).

The EFP is subject to coupled social-ecological interpretations as its boundaries are subject to biophysical and anthropogenic interpretations (Angelstam et al. 2013, Reise and Knottnerus 2015). For our interviews, we mentioned to our interviewees that we focused on the coastal area between Dollart Bay and Jade Bay. However, we left it open to them where they drew their personal anthropogenic boundary of the landscape. We used the term "coastal area" rather than EFP in the interviews because this might have resulted in different emotional reactions based on the historic separation of the area into East Frisia (Ostfriesland) and Frisia (Friesland).

\section{Data analysis}

We aggregated the named stakeholders from all interviews and categorized them into groups. Our aim was to create stakeholder groups that were consistent enough that all named stakeholders would fit into one group. We tried to use names for the stakeholder groups that interviewees also used. For example, we grouped the individually named environmental nongovernmental organizations (ENGOs) (e.g., Greenpeace, Friends of the Earth (BUND)) into 
Table 1. The 25 stakeholder groups and their times mentioned, their aggregated influence, their betweenness and degree centrality values, and the type of influence they hold. The table is organized according to "times mentioned." Label abbreviations: Water - water boards including drinking water, drainage, and flood control; Env. admin - environmental administration; Renewable - renewable energies except wind energy; Resources - resource extraction and storage; Energy energy infrastructure and nonrenewable energy provision; Heritage - heritage, tradition, and culture associations; Media local media. Types of influence: legal (J), political (P), land (L), and financial (M). Letters are lowercase if a stakeholder group has limited influence of this type. If there is no letter given, the stakeholder group does not have this type of influence.

\begin{tabular}{|c|c|c|c|c|c|c|c|c|}
\hline Stakeholder group & Times mentioned & Influence & Betweenness & Degree & \multicolumn{4}{|c|}{ Influence type } \\
\hline Agriculture & 19 & 50 & 0.15 & 43 & & $\mathrm{P}$ & & \\
\hline Municipalities & 18 & 43 & 0.09 & 40 & $\mathrm{~J}$ & $\mathrm{P}$ & & \\
\hline ENGOs & 18 & 25 & 0.06 & 39 & $\mathrm{j}$ & $\mathrm{p}$ & 1 & \\
\hline County & 17 & 36 & 0.07 & 37 & $\mathrm{~J}$ & $\mathrm{P}$ & $\mathrm{L}$ & M \\
\hline Tourism & 17 & 29 & 0.09 & 38 & $\mathrm{~J}$ & $\mathrm{P}$ & & $\mathrm{m}$ \\
\hline Water & 15 & 29 & 0.03 & 35 & $\mathrm{j}$ & $\mathrm{P}$ & & \\
\hline National Park & 15 & 25 & 0.01 & 20 & $\mathrm{~J}$ & & & \\
\hline Wind Energy & 15 & 24 & 0.09 & 18 & $\mathrm{~J}$ & & 1 & $\mathrm{M}$ \\
\hline State & 14 & 32 & 0.01 & 24 & $\mathbf{J}$ & $\mathrm{P}$ & & M \\
\hline Businesses & 14 & 28 & 0.01 & 20 & & & & M \\
\hline Env. admin & 14 & 24 & 0.02 & 25 & $\mathbf{J}$ & & & $\mathrm{m}$ \\
\hline Transport & 13 & 14 & 0.01 & 18 & & $\mathrm{p}$ & 1 & $\mathrm{~m}$ \\
\hline Citizens & 11 & 22 & 0.01 & 21 & & $\mathrm{P}$ & $\mathrm{L}$ & \\
\hline Harbor & 11 & 12 & 0.00 & 9 & & $\mathrm{p}$ & 1 & M \\
\hline Renewable & 8 & 13 & 0.00 & 8 & $\mathbf{J}$ & $\mathrm{p}$ & 1 & M \\
\hline Resources & 8 & 9 & 0.00 & 5 & & & 1 & $\mathrm{M}$ \\
\hline Forestry & 8 & 8 & 0.00 & 6 & $\mathbf{J}$ & & $\mathrm{L}$ & $\mathrm{m}$ \\
\hline Energy & 7 & 11 & 0.00 & 13 & $\mathbf{J}$ & & & M \\
\hline EU & 6 & 8 & 0.00 & 5 & $\mathbf{J}$ & $\mathrm{P}$ & & M \\
\hline Fishery & 6 & 6 & 0.00 & 7 & & & & \\
\hline Research & 4 & 4 & 0.01 & 20 & & & & \\
\hline Federal & 2 & 5 & 0.00 & 1 & $\mathbf{J}$ & $\mathrm{P}$ & & $\mathrm{M}$ \\
\hline Heritage & 2 & 3 & 0.00 & 6 & & & & \\
\hline Media & 2 & 2 & 0.00 & 4 & & & & \\
\hline Army & 1 & 1 & 0.00 & 2 & $\mathbf{J}$ & & & \\
\hline
\end{tabular}

the stakeholder group ENGOs because some of our interviewees named specific ENGOs, and others used ENGOs as a collective term.

We digitized and analyzed all individual networks using the open source software Gephi (Bastian et al. 2009). In addition, we used R ( R Core Team 2013) to calculate correlation values. Furthermore, we created one aggregated social network combining the individual networks in order to identify the dominant perspectives. To create the aggregated network, we counted how often a relationship between two stakeholder groups was mentioned across all interviews, how often the stakeholder groups were mentioned in the individual interviews, and what their average assigned influence was.

For the aggregated social network, we calculated the betweenness centrality and their degree of centrality for each stakeholder group using corresponding tools in Gephi (Table 1). Centrality calculations illustrate the connectedness between nodes. The betweenness centrality indicates how well a stakeholder can connect between two unconnected stakeholders. The degree of centrality indicates how well a stakeholder is directly connected to other stakeholders (de Nooy et al. 2005). In addition, we calculated the Pearson correlation between aggregated influence levels and frequency of being named at all in an interview.

We transcribed and qualitatively analyzed the interviews. After the transcription. we coded the interviews following Mayring's (2015) inductive category formation process using MAXQDA
(MAXQDA 2018). Codes related to the different stakeholder groups, relationships, influence, and the EFP (the list of codes is provided in Appendix 1). Lastly, we grouped the descriptions of the relationships and influence into different types of relationships and influence.

In the following, for privacy reasons, we refer to the interviewees in parentheses using anonymized codes consisting of capitalized letters, and numbers if we interviewed multiple stakeholders from the same background (Appendix 1). We created the codes so that the reader can interpret the interviewee's background (e.g., AGRI for agriculture) but the individual remains anonymous. The following results are based on the statistical network calculations and on the coded interviews.

\section{RESULTS}

\section{Stakeholders}

When asked who influenced the development of the EFP, we got a list of 111 individuals and organizations. The interviewees named between eight and 41 individual stakeholders. We grouped the 111 named stakeholders into 25 stakeholder groups (Table 1). The five most often named stakeholder groups were agriculture, municipalities, ENGOs, counties, and tourism. The individual interviewees named stakeholders belonging to different stakeholder groups with a median value of 13 , showing that most interviewees were aware of stakeholders from various stakeholder groups across political levels and sectors. 


\section{Relationships and perceived influence}

Our interviewees named between two and 15 personal relationships to other stakeholders (Table 2). On average, the interviewees were connected to about half of the stakeholders they named. However, the range was between $11 \%$ and $92 \%$ (Table 2 ). There is only a weak positive correlation (Pearson $r=0.29$ ) between the number of named stakeholder groups and the number of relationships. The interviewees also named relationships that did not include them.

Table 2. Quantitative representation of stakeholders and relationships named during interviews.

\begin{tabular}{lcccc}
\hline Interviewee & $\begin{array}{c}\text { Named } \\
\text { stakeholders }\end{array}$ & $\begin{array}{c}\text { Own } \\
\text { relationships }\end{array}$ & $\begin{array}{c}\text { Relationships } \\
\text { of others }\end{array}$ & $\begin{array}{c}\text { Unconnected } \\
\text { stakeholders }\end{array}$ \\
\hline AGR1 & 19 & 14 & 2 & 4 \\
PLAN & 19 & 3 & 0 & 15 \\
STATE2 & 19 & 2 & 26 & 2 \\
WAT1 & 18 & 9 & 8 & 4 \\
WAT2 & 16 & 12 & 17 & 3 \\
RES & 15 & 11 & 37 & 1 \\
CON1 & 14 & 8 & 10 & 5 \\
EADMIN1 & 14 & 7 & 17 & 2 \\
CON2 & 13 & 4 & 8 & 4 \\
CON3 & 13 & 8 & 8 & 2 \\
MUN & 13 & 12 & 10 & 1 \\
STATE1 & 13 & 11 & 18 & 0 \\
TOU & 13 & 11 & 0 & 2 \\
AGR2 & 12 & 5 & 11 & 2 \\
STATE3 & 12 & 7 & 15 & 1 \\
DEV & 11 & 10 & 4 & 1 \\
EADMIN2 & 11 & 5 & 6 & 1 \\
WIND & 9 & 6 & 10 & 1 \\
AGR3 & 7 & 6 & 5 & 3 \\
CHU & 5 & 1 & & 1 \\
\hline
\end{tabular}

In most interviews, few stakeholders were named that were not connected to any other stakeholder groups (Table 2). Stakeholder groups that were frequently not linked to other stakeholder groups include the EU, harbor, business, resources, state administration, wind energy, and citizens. The stakeholder groups business, state administration, and wind energy have high betweenness centrality values. This indicates that these stakeholder groups are able to connect less connected stakeholder groups to other stakeholder groups.

Our interviewees often named relationships between stakeholder groups that they also perceived as influential (Fig. 2). We inductively identified five different types of relationships: formalized, institutionalized, informal, sporadic, and none (detailed description in Appendix 1). The naming, understanding, and definitions of the five types is specific to our study. Formalized relationships are either (1) membership and ownership tightly connecting stakeholder groups, or (2) (written) statements that may be made, e.g., during planning processes ${ }^{[1]}$. Institutionalized relationships are not based on legal requirements and they are defined as inclusive because they aim at collaboration and information exchange between one or multiple stakeholder groups. Informal relationships are based on personal relationships within or beyond an individual's own sector. Sporadic relationships exist if, for example, only one side is interested in the relationship, platforms for exchange are missing, or stakeholders have conflicting interests. Sometimes there is no relationship because stakeholders explicitly do not want to be connected due to opposing interests or because they are unable to identify the right contact person. Besides the willingness of a stakeholder to connect with others, practical parameters also affect the character of relationships. Our interviewees talked about parameters such as the level of professionalism, the knowledge about platforms to meet, and the availability of resources such as time and money.

Agriculture, municipalities, and counties have the highest aggregated perceived influence (Table 1). All three were also mentioned often. Eight of our 20 interviewees named agriculture as the most influential stakeholder group. Public administration bodies combined from all levels (municipality to national) were named nine times as the most important (Appendix 1). Although the frequency of being named and influence are strongly correlated (Pearson $r=0.92$ ), there are some exceptions. For example, state administration was mentioned less often than ENGOs, but its aggregated influence level was higher. This means that if interviewees named the state administration, they perceived it as influential, whereas many interviewees named ENGOs but assigned little influence to them (Table 1).

We identified four different kinds of influence: legal, political, land, and financial (Table 1; detailed description in the Appendix 1). Legal influence is mainly achieved through laws and strengthened by judicial decisions. Political influence describes the process of how laws are formulated and how groups can influence the process through various forms of lobbying. Land as an influential factor originates from interviewees saying that, in the end, landowners decide what happens with the land. Lastly, financial resources can direct decisions, as most have an interest in earning money or at least not losing it.

We find that most interviewees hardly attribute any influence to themselves (Appendix 1). Three-quarters of our interviewees assigned no or only one of ten bricks to themselves. An exception was a mayor who assigned most bricks to the municipality. However, he stressed the influence of the municipal council as a decision-making body and that he held less influence than the council. This means that while he acknowledged the influence of his stakeholder group, he did not recognize his own influence as high.

Agriculture, municipalities, counties, the state, ENGOs, wind, and tourism were perceived as the most influential. However, their influence varied in type and degree. Agriculture is connected to many stakeholder groups (Fig. 2) and has mainly political and land influence. Farmers are well organized in farmers' associations, with branches at each political level. These associations take part in institutionalized and informal meetings with other stakeholder groups to exchange information. They represent their members' interests to decision makers. In addition, farmers are often also council members in municipalities and counties. Agriculture dominates the physical appearance of the landscape, and farmers have a large impact through their landuse decisions on the development of land. Legal and economic constraints influence farmers.

Municipalities and counties are the administrative levels responsible for local and regional planning. As such, they are 
Fig. 2. Aggregated social network of the EFP as perceived by interview partners. Color intensity represents the betweenness centrality value (the redder/darker, the higher). Width and line color show how often a certain relationship was mentioned. The size of the bubbles illustrates the perceived influence (the bigger, the more influential).

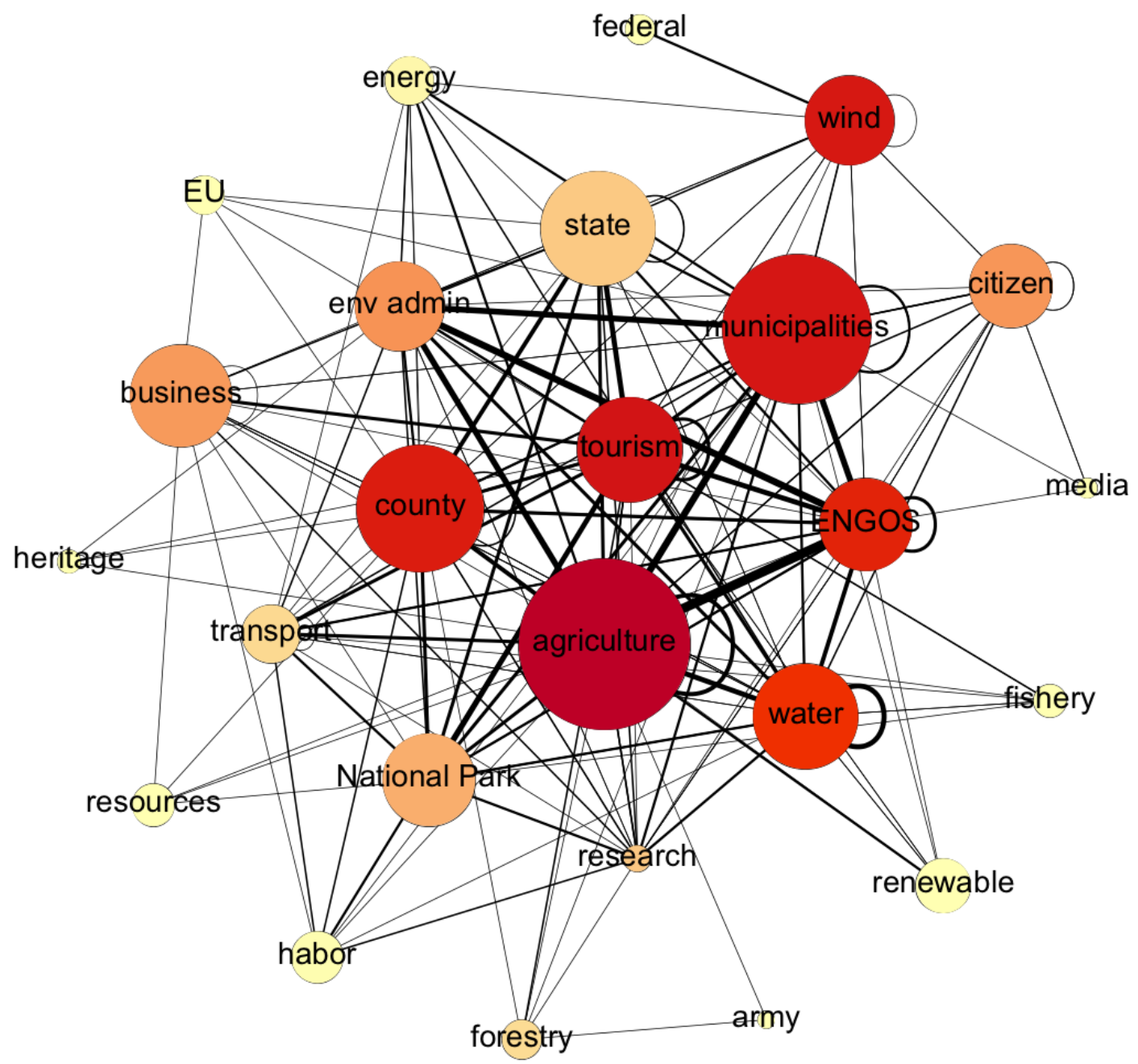

formally well connected with public agencies via written statements. They have high legal and political influence through spatial planning. They make the plans that determine land-use possibilities and that are approved by the municipal and county council. Information flow exists outside formalized planning: some administrations organize institutionalized meetings to inform stakeholder groups about current and upcoming activities, whereas other administrations share this information in informal settings.

The federal state (administration and government) is less connected with local stakeholder groups. The state capital is perceived as "far away" (AGR2). The state has little influence on people's everyday lives. Nevertheless, it sets the guiding rules for spatial planning at more local levels and has legal, political, and monetary influence (Table 1). Our interviewees see almost no possibility of directly influencing the state-level organizations themselves due to missing links and they did not mention elections as a way to influence. Agricultural and environmental organizations have state-level branches, which conduct these tasks. The state administration has monetary influence because it grants EU agrarian subsidies. Thus, for farmers, it is the most tangible administrative level in connection with these subsidies. The combination of different influence types might be the reason why, if named, the state level was perceived as influential.

Environmental NGOs are well connected, as illustrated by the betweenness centrality value and the degree values (Table 1; Fig. 2). They have different types of relationships. They have the right to contribute with written statements, e.g., during planning processes, and are involved in institutionalized and informal relationships within and beyond their stakeholder group. However, they seem not to hold a specific influence. Interviewees described ENGOs as relevant but not influential, meaning that 
their concerns were important for the landscape, but they did not necessarily have the influence to push decisions in any direction.

Wind energy caused "the biggest [change of landscape] that we had in the last decades" (EADMIN1) because "the landscape looks different" (MUN). Direct relationships with the wind sector are uncommon: investors and the national government are major players in that group with monetary and political influence, but they are not on site. Investors seem less concerned with the development of the landscape and "[...] realize their demands and do not think about the development of the landscape" (EADMIN1).

Tourism was perceived as influential. Nevertheless, interviewees "[...] have problems to gain an overview of the tourism experts on the EFP. There are different ones. I miss a unity between them" (AGR1). Although a regional tourism organization exists, many interviewees were only aware of municipal ones and "perceive them very rarely as [involved] stakeholders" (CON2).

\section{The landscape as an operational unit}

The interviewees described the history of the landscape as a basis for understanding the present. Over the last centuries, humans have created the landscape using land reclamation and coastal protection, resulting in a cultural landscape in "which basically nothing [is] natural" (RES). The "cultural landscape forms a symbiosis with the farmer" (AGR3). Aside from ongoing draining of the land and coastal protection measurements (e.g., maintenance of dikes), financial subsidies are paid to maintain landscape elements such as hedge banks, which are traditional, labor-intensive hedgerow elements in the landscape.

The local identity is strong and important, with Low German (Plattdeutsch), the local language, as an essential part of this identity. In interviews, local residents were described as more connected with the landscape than people elsewhere in the state, and as "real fighters (German: zäher Hund)" (MUN) referring to the geographic position and the land-reclamation processes. Local farms are mostly family operated, with the goal of leaving a prosperous farm for the next generation, and are managed differently than large-scale farms whose objective is profit maximization. Overall, there is an understanding that all stakeholder groups "try to explore the best option for our home (German: Heimat)" (DEV) as "we all [...] live in this area" (AGR1).

The landscape spans across multiple municipalities and counties, but most stakeholder groups act within existing political boundaries (i.e., municipality, county). Many organizations have a hierarchical structure with branches at each political level. It is challenging to define which group on which level should be included on the landscape level. Where relationships across municipalities and counties exist, they are mostly institutionalized or informal within a single stakeholder group.

Some stakeholder groups seem to function on a different level (e.g., national). Wind energy and tourism are perceived as influential stakeholder groups, but interviewees had difficulty identifying concrete representatives of these groups. Both sectors were seen to be creating economic opportunities, but our interviewees had hardly any relationships with them. Their operational units do not correspond to those of the other stakeholders.

\section{DISCUSSION}

\section{Intangible stakeholders}

We identified two kinds of stakeholder groups: tangible and intangible. For tangible stakeholder groups, our interviewees could give us concrete names of representatives, whereas for intangible groups, they had problems doing so. For example, the headquarters of one of the largest German energy companies and of a wind turbine producer are located in the study area, but the companies claimed that none of their employees were qualified to talk about the regional situation on the EFP. Wind energy, which has visually changed the landscape, is another example. Although interviewees identified the wind energy sector as influential, they could not name specific representatives of this stakeholder group.

We speculate that the intangible groups might act on different levels and may be less grounded at the local level. However, stakeholders on the EFP still perceive them to be locally influential. This might be a pitfall of landscape stewardship because certain groups might not see the reason to act if they think that not everybody will join the effort. Feedback mechanisms across scales and missing cross-level interactions between stakeholders are challenges for collaboration and stewardship (Cockburn et al. 2018). Scale-crossing brokers could act as catalysts because they might be capable of integrating intangible groups into governance structures to motivate local stewardship (Ernstson et al. 2010). In an EU context, LEADER groups could, for example, act as such midscale managers. On the EFP, the biosphere reserve could serve as such a catalyst by bringing together different political levels and sectors in the transition zone.

\section{Acknowledging existing structures}

The EFP is not a void, and any new governance approach for the transition zone must acknowledge the existing social structures. Local stakeholders are aware of and connected to various stakeholder groups at different levels and in diverse sectors. Some already work cross-sectorally in nonformalized relationships. These existing relationships could be leveraged to develop landscape stewardship without having to start from scratch. Consideration of practical barriers (e.g., available resources) is important for successfully establishing landscape stewardship.

Different levels and kinds of influence should be acknowledged as major factors in governance processes (Akbulut and Soylu 2012, Stone-Jovicich 2015). Our interviewed stakeholders did not only perceive others as always being more influential, but they also described different kinds of influence. The four inductively identified kinds of influence correspond with influence types in publications using deductive reasoning (e.g., Laterra et al. 2018). These bundles of power illustrate that stakeholders can influence different parts of the process (e.g., material decision vs. discourse formulation) and that the local circumstances are made up of the interaction between social structures and the stakeholder (Ribot and Peluso 2003, Raik et al. 2008, Fabinyi et al. 2014). Power asymmetries among stakeholders are a challenge for collaboration and difficult to balance in real processes (Barnaud and van Paassen 2013, Cockburn et al. 2018).

For the EFP, we found several stakeholders - a LEADER group, an independent agricultural research center, the Biosphere Reserve administration - that could serve as catalysts to bring 
potential stewards together. These stakeholders are well connected to groups at different levels and in various sectors and are perceived as having medium influence (Ernstson et al. 2010). However, only the Biosphere Reserve administration has an interest in a coordinated governance process for the whole EFP. Other stakeholder groups might be more powerful, but this might be a problem because less influential stakeholders might fear that the more influential one will take control of the process (Gustafsson et al. 2015, Bixler et al. 2016b, Fish et al. 2016). A pitfall facing the Biosphere Reserve is that people have trouble differentiating it from the National Park (Winkler 2019). One reason for this is likely that the Biosphere Reserve and the National Park are currently almost spatially identical and managed by the same agency. However, the phenomenon exists even for biosphere reserves with distinct transition zones and without a National Park close by. People connect the term Biosphere Reserve more strongly with nature conservation than with sustainable development (Hernes and Metzger 2017). To increase public recognition of its mission, the Biosphere Reserve administration should step out of the shadow of the National Park and clearly communicate its objectives for the transition zone.

\section{Landscape as a governance unit}

The EFP as a human-made landscape has an identity-establishing and unifying character for local residents and represents an indivisible entanglement of the sociocultural system (including local history, language, customs) and the ecological system. Interviewees related more strongly to the landscape than to clearly delineated political boundaries. Feelings of place attachment and belonging were connected to the surrounding landscape. As such, the landscape on the EFP represents the interwoven connections between stewardship, place, and community (Baldwin et al. 2017) and may well function as an operational unit that can motivate people to act as stewards by stressing social-cultural relationships with the physical space (Chapin et al. 2015). These relational values have been identified as catalysts to motivate landscape stewardship among local stakeholders (Lynham et al. 2017, Peçanha Enqvist et al. 2018, West et al. 2018).

A pitfall in using landscapes to motivate stewardship may be the scale mismatch between landscapes and political boundaries. Creating a perfect fit between governance processes and spatial units is elusive as systems are overlapping (Moss 2012). Misfit between political and natural (e.g., catchment, landscape) units makes it challenging to find stakeholders to serve as committed and responsible stewards (Kastens and Newig 2008). In our case, the wind energy sector seems to be more active on a national level despite its impacts on the local landscape. On the other hand, municipalities promoting tourism locally try to maximize their individual benefits without seeing the potential benefits of a coordinated strategy. As social networks include actors from multiple levels (Alexander and Armitage 2015), the landscape might serve as a catalyst to bring them together if they are recognized to consider the relevance of other levels.

New modes of administrative operation would need to be found for landscape-oriented governance of the extended transition zone. One example of governance within natural boundaries is the European Water Framework Directive (WFD) that uses water catchments as its operation unit (Hering et al. 2010). The effectiveness of the WFD is still debatable (Moss 2008), and new forms of governance can lead to a loss of transparency and legitimacy of decision making (Newig et al. 2016). However, despite these issues, the WFD demonstrates that it is possible to implement landscape-oriented governance systems within Germany's existing hierarchical decision-making structures (Moss 2004).

\section{Methodological reflection}

Net-Map enabled interactive conversations with interviewees about their networks. However, due to the spatial extent of the EFP, this method revealed a great number of stakeholders. Interviewees often named individual representatives of organizations. In order to combine and compare the individual networks, we decided to group them. This reduced complexity but also details, e.g., about individual perceptions. In addition, we use generalizations by talking, e.g., about agriculture as a homogenous group despite the fact that within the sector there are various groups with different connections.

We learned how interviewees perceived the societal structures through their networks, descriptions, and explanations. This information is subjective to the interviewee. We see the strength of Net-Map in its ability to reveal information about relationships as they are perceived compared with how relationships are presented in official documentation.

\section{CONCLUSION}

We recognize that it is hard to generalize our findings (Frank 2011, Alexander and Armitage 2015), but our study presents the case of an area where a new governance process is going to be established within already existing societal structures. These situations have attracted less attention in research so far, and we hope to see more such studies in the future in order to be able to make comparisons and draw more generalizable conclusions.

The decision makers of the Biosphere Reserve face the same challenges as we did: the need to make operational decisions with the risk of losing details, the large spatial extent of the area, limited resources, and the difference between perceived and "official" reality. We hope our research can contribute to the successful extension of the Biosphere Reserve on the EFP, but also inform other areas where new governance approaches will be established.

The EFP has the potential for landscape stewardship because the characteristics of the stakeholders could function as catalysts. Local stakeholders are already somewhat connected, possess influence on different levels and of various types, and hold certain perceptions of the societal structures. State and nonstate stakeholders from agriculture, nature conservation, tourism, water, and coastal protection could function as stewards because they care for the landscape. As such, the landscape fulfills a unifying and identity-establishing character.

However, pitfalls could hamper the initiation of landscape stewardship. Stakeholders assign influence and as such responsibility to act to other stakeholders rather than to themselves. The landscape has so far gained little attention in local governance approaches, and it might be challenging to increase it as it does not align with existing political units.

As a concrete next step, the Biosphere Reserve administration could initiate a process guided by the idea of landscape 
stewardship, highlighting the different types of influence in order to show that each stakeholder group holds influence. This might encourage stakeholders to take on responsibility and acknowledge their abilities rather than assigning influence and responsibility to others. To strengthen the landscape perspective, one way forward could be the identification of overarching themes of importance for people and nature such as demographic change or biodiversity. These themes fit well with sustainable development which is the objective of the transition zone in a biosphere reserve.

Responses to this article can be read online at: http://www.ecologyandsociety.org/issues/responses. php/10982

\section{Acknowledgments:}

We thank our 20 interview partners, who were willing to participate in an interview with a method they did not know. We appreciate their honesty, time, thoughts, and explanations. Klara J. Winkler acknowledges financial support by the Universitätsgesellschaft (UGO) for her participation in the Resilience2017 conference. We thank Ciara Raudsepp-Hearne, Erika Yates, Jesse Rieb, Joseph G. Gasser, Julie Botzas-Coluni, Marie Dade, Stefan Partelow, as well as Klara J. Winkler's PhD committee for comments and language editing on earlier versions of the manuscript. We appreciate the help of Jesse Rieb with Figure 1. The thorough comments of two reviewers helped to greatly improve our paper.

\section{LITERATURE CITED}

Alexander, S. M., M. Andrachuk, and D. Armitage. 2016. Navigating governance networks for community-based conservation. Frontiers in Ecology and the Environment 14(3):155164. https://doi.org/10.1002/fee.1251

Alexander, S. M., and D. Armitage. 2015. A social relational network perspective for MPA science. Conservation Letters 8 (1):1-13. https://doi.org/10.1111/conl.12090

Akbulut, B., and C. Soylu. 2012. An inquiry into power and participatory natural resource management. Cambridge Journal of Economics 36(5):1143-1162. https://doi.org/10.1093/cje/ $\underline{\mathrm{bes} 034}$

Angelstam, P., M. Grodzynskyi, K. Andersson, R. Axelsson, M. Elbakidze, A. Khoroshev, I. Kruhlov, and V. Naumov. 2013. Measurement, collaborative learning and research for sustainable use of ecosystem services: landscape concepts and Europe as laboratory. AMBIO 42(2):129-145. https://doi.org/10.1007/ s13280-012-0368-0

Baldwin, C., T. Smith, and C. Jacobson. 2017. Love of the land: social-ecological connectivity of rural landholders. Journal of Rural Studies 51:37-52. https://doi.org/10.1016/j.jrurstud.2017.01.012

Barnaud, C., and A. van Paassen. 2013. Equity, power games, and legitimacy: dilemmas of participatory natural resource management. Ecology and Society 18(2): 21. https://doi. org/10.5751/ES-05459-180221
Bastian, M., S. Haymann, and M. Jacomy. 2009. Gephi: an open source software for exploring and manipulating networks. Proceedings of the Third International Conference on Weblogs and Social Media. 17-20 May 2009, San Jose, California, USA. [online] URL: file:///C:/Users/Caroline/Downloads/ Gephi_An_Open_Source_Software_for_Exploring_and_Ma.pdf

Behre, K.-E., and H. van Lengen, editors. 1995. Ostfriesland: Geschichte und Gestalt eine Kulturlandschaft. Ostfriesische Landschaft, Aurich, Germany.

Belaire, J. A., A. K. Dribin, D. P. Johnston, D. J. Lynch, and E. S. Minor. 2011. Mapping stewardship networks in urban ecosystems. Conservation Letters 4(6):464 473. https://doi. org/10.1111/j.1755-263X.2011.00200.X

Bennett, N. J. 2016. Using perceptions as evidence to improve conservation and environmental management. Conservation Biology 30(3):582-592. https://doi.org/10.1111/cobi.12681

Bennett, N. J., T. S. Whitty, E. Finkbeiner, J. Pittman, H. Bassett, S. Gelcich, and E. H. Allison. 2018. Environmental stewardship: a conceptual review and analytical framework. Environmental Management 61(4):597-614. https://doi.org/10.1007/s00267-017-0993-2

Berbés-Blázquez, M., J. A. González, and U. Pascual. 2016. Towards an ecosystem services approach that addresses social power relations. Current Opinion in Environmental Sustainability 19:134-143. https://doi.org/10.1016/j.cosust.2016.02.003

Bixler, R. P., S. Johnson, K. Emerson, T. Nabatchi, M. Reuling, C. Curtin, M. Romolini, and J. M. Grove. 2016a. Networks and landscapes: a framework for setting goals and evaluating performance at the large landscape scale. Frontiers in Ecology and the Environment 14(3):145-153. https://doi.org/https://doi. org/10.1002/fee. 1250

Bixler, R. P., D. M. Wald, L. A. Ogden, K. M. Leong, E. W. Johnston, and M. Romolini. 2016b. Network governance for large-scale natural resource conservation and the challenge of capture. Frontiers in Ecology and the Environment 14(3):165-171. https://doi.org/https://doi.org/10.1002/fee.1252

Bodin, Ö., and C. Prell. 2011. Social network analysis in natural resource governance: summary and outlook. Pages 347-373 in Ö. Bodin and C. Prell, editors. Uncovering the social fabric of environmental governance. Cambridge University Press, Cambridge, UK. https://doi.org/10.1017/CBO9780511894985.015

Brunckhorst, H., H. Farke, P. Körber, and P. Potel. 1995. Biosphärenreservate Schleswig-Holsteinisches, Hamburgisches und Niedersächsisches Wattenmeer. Pages 61-111 in Ständige Arbeitsgruppe der Biosphärenreservate in Deutschland, editor. Biosphärenreservate in Deutschland - Leitlinien für Schutz, Pflege und Entwicklung. Springer, Berlin Heidelberg, Germany. https:// doi.org/10.1007/978-3-642-57824-3 2

Buck, L. E., S. J. Scherr, C. M. Planicka, and K. Heiner. 2017. Building partnerships for landscape stewardship. Pages 57-77 in C. Bieling and T. Plieninger, editors. The science and practice of landscape stewardship. Cambridge University Press, Cambridge, UK. https://doi.org/10.1017/9781316499016.007

Bund für Umwelt und Naturschutz Deutschland (BUND). 2015. Niedersächsisches Wattenmeer: Mehr Miteinander. BUNDmagazin 
2015 (1):26-27. [online] URL: https://www.bund.net/fileadmin/ user_upload_bund/publikationen/bund/bundmagazin/ bund bundmagazin 1 2015.pdf https://doi.org/https://doi. org/10.1002/9783527678471.hbnl2006003

Bundesamt für Naturschutz $(\mathrm{BfN})$. 2017. Biosphärenreservate in Deutschland. [online] URL: https://www.bfn.de/fileadmin/BfN/ gebietsschutz/Dokumente/BR Tab 062017 barrierefrei.pdf

Cebrián-Piqueras, M. A., L. Karrasch, and M. Kleyer. 2017. Coupling stakeholder assessments of ecosystem services with biophysical ecosystem properties reveals importance of social contexts. Ecosystem Services 23:108-115. https://doi.org/10.1016/ j.ecoser.2016.11.009

Chan, K. M. A., P. Balvanera, K. Benessaiah, M. Chapman, S. Díaz, E. Gómez-Baggethun, R. Gould, N. Hannahs, K. Jax, S. Klain, G. W. Luck, B. Martín-López, B. Muraca, B. Norton, K. Ott, U. Pascual, T. Satterfield, M. Tadaki, J. Taggart, and N. J. Turner. 2016. Why protect nature? Rethinking values and the environment. Proceedings of the National Academy of Sciences 113(6):1462-1465. https://doi.org/10.1073/pnas.1525002113

Chapin, F. S. 2017. Ecological foundations of landscape stewardship. Pages 21-34 in C. Bieling and T. Plieninger, editors. The science and practice of landscape stewardship. Cambridge University Press, Cambridge, UK. https://doi.org/10.1017/9781316499016.003

Chapin, F. S., S. R. Carpenter, G. P. Kofinas, C. Folke, N. Abel, W. C. Clark, P. Olsson, D. M. S. Smith, B. Walker, O. R. Young, F. Berkes, R. Biggs, J. M. Grove, R. L. Naylor, E. Pinkerton, W. Steffen, and F. J. Swanson. 2010. Ecosystem stewardship: sustainability strategies for a rapidly changing planet. Trends in Ecology and Evolution 25(4):241-249. https://doi.org/10.1016/j. tree.2009.10.008

Chapin, F. S., A. F. Mark, R. A. Mitchell, and K. J. M. Dickinson. 2012. Design principles for social-ecological transformation toward sustainability: lessons from New Zealand sense of place. Ecosphere 3(5): 40. https://doi.org/10.1890/ES12-00009.1

Chapin, F. S., M. Sommerkorn, M. D. Robards, and K. HillmerPegram. 2015. Ecosystem stewardship: a resilience framework for arctic conservation. Global Environmental Change 34:207-217. https://doi.org/10.1016/j.gloenvcha.2015.07.003

Cockburn, J., G. Cundill, S. Shackleton, and M. Rouget. 2018. Towards place-based research to support social-ecological stewardship. Sustainability 10(5):1-21. https://doi.org/10.3390/ $\underline{\text { su10051434 }}$

Common Wadden Sea Secretariat. (n.d.). The Wadden Seaworld wide unique. [online] URL: http://www.waddenseasecretariat.org/about-us/about-the-wadden-sea

Conrad, E. 2017. Human and social dimensions of landscape stewardship. Pages 38-53 in C. Bieling and T. Plieninger, editors. The science and practice of landscape stewardship. Cambridge University Press, Cambridge, UK. https://doi.org/10.1017/9781$\underline{316499016.005}$

de Nooy, W., A. Mrvar, and V. Batagelj. 2005. Exploratory social network analysis with pajek. Cambridge University Press, Cambridge, UK. https://doi.org/https://doi.org/10.1017/

cbo9780511806452
Enqvist, J., M. Tengö, and Ö. Bodin. 2014. Citizen networks in the garden city: protecting urban ecosystems in rapid urbanization. Landscape and Urban Planning 130(1):24-35. https://doi.org/10.1016/j.landurbplan.2014.06.007

Epstein, G., J. Pittman, S. M. Alexander, S. Berdej, T. Dyck, U. Kreitmair, K. J. Rathwell, S. Villamayor-Tomas, J. Vogt, and D. Armitage. 2015. Institutional fit and the sustainability of socialecological systems. Current Opinion in Environmental Sustainability 14:34 40. https://doi.org/10.1016/j.cosust.2015.03.005

Ernstson, H., S. Barthel, E. Andersson, and S. Borgström. 2010. Scale-crossing brokers and network governance of urban ecosystem services: the case of Stockholm. Ecology and Society 15(4): 18. https://doi.org/10.5751/ES-03692-150428

Fabinyi, M., L. Evans, and S. J. Foale. 2014. Social-ecological systems, social diversity, and power: insights from anthropology and political ecology. Ecology and Society 19(4): 28. https://doi. org/10.5751/ES-07029-190428

Felipe-Lucia, M. R., B. Martín-López, S. Lavorel, L. BerraqueroDíaz, J. Escalera-Reyes, and F. A. Comín. 2015. Ecosystem services flows: why stakeholders' power relationships matter. PLoS ONE 10(7):1-21. https://doi.org/10.1371/journal.pone.0132232

Fischer, A. P. 2015. A boundary-spanning organization for transdisciplinary science on land stewardship: the stewardship network. Ecology and Society 20(4): 38. https://doi.org/10.5751/ ES-08121-200438

Fish, R., E. Saratsi, M. S. Reed, and H. Keune. 2016. Stakeholder participation in ecosystem service decision-making. Page 629 in M. Potschin, R. H. Haines-Young, R. Fish, and R. K. Turner, editors. Routledge handbook of ecosystem services. Routledge, New York, New York, USA. https://doi.org/10.4324/9781315775302-23

Folke, C., G. P. Kofinas, and F. S. Chapin, editors. 2009. Principles of ecosystem stewardship: resilience-based natural resource management in a changing world. Springer, New York, New York, USA. https://doi.org/https://doi.org/10.1007/978-0-387-73033-2

Frank, K. A. 2011. Social network models for natural resource use and extraction. Pages 180-205 in O. Bodin and C. Prell, editors. Social networks and natural resource management. Cambridge University Press, Cambridge, UK. https://doi. org/10.1017/CBO9780511894985.009

Gailing, L., and M. Leibenath, editors. 2013. Neue Energielandschaften -Neue Perspektiven der Landschaftsforschung. Springer Fachmedien Wiesbaden, Wiesbaden, Germany. https:// doi.org/10.1007/978-3-531-19795-1

Glückselig, D. 2016. Existenzangst treibt Bauern auf Barrikaden. NWZonline. [online] URL: https://www.nwzonline.de/wesermarsch/ wirtschaft/existenzangst-treibt-bauern-auf-barrikade_a_31,0,995117516. $\underline{\mathrm{html}}$

Gustafsson, S., J. Ivner, and J. Palm. 2015. Management and stakeholder participation in local strategic energy planning Examples from Sweden. Journal of Cleaner Production 98:205212. https://doi.org/10.1016/j.jclepro.2014.08.014

Hanz, M. 2018. Entwicklungszone: Bauern sehr skeptisch. NWZonline. [online] URL: https://www.nwzonline.de/friesland/ wirtschaft/wangerland-naturschutz-entwicklungszone-bauern-sehrskeptisch a 50,2,1268817875.html 
Hauck, J., C. Stein, E. Schiffer, and M. Vandewalle. 2015. Seeing the forest and the trees: facilitating participatory network planning in environmental governance. Global Environmental Change 35:400-410. https://doi.org/10.1016/j.gloenvcha.2015.09.022

Hering, D., A. Borja, J. Carstensen, L. Carvalho, M. Elliott, C. K. Feld, A.-S. Heiskanen, R. K. Johnson, J. Moe, and D. Pont. 2010. The European Water Framework Directive at the age of 10: a critical review of the achievements with recommendations for the future. Science of The Total Environment 408(19):4007-4019. https://doi.org/https://doi.org/10.1016/j.scitotenv.2010.05.031

Hernes, M. I., and M. J. Metzger. 2017. Understanding local community's values, worldviews and perceptions in the Galloway and Southern Ayrshire Biosphere Reserve, Scotland. Journal of Environmental Management 186:12-23. https://doi.org/10.1016/j. jenvman.2016.10.040

Ishwaran, N., A. Persic, and N. H. Tri. 2008. Concept and practice: the case of UNESCO biosphere reserves. International Journal of Environment and Sustainable Development 7(2): 118. https://doi.org/10.1504/IJESD.2008.018358

Karrasch, L., T. Klenke, and J. Woltjer. 2014. Linking the ecosystem services approach to social preferences and needs in integrated coastal land use management - a planning approach. Land Use Policy 38:522-532. https://doi.org/10.1016/j. landusepol.2013.12.010

Karrasch, L., M. Maier, M. Kleyer, and T. Klenke. 2017. Collaborative landscape planning: co-design of ecosystem-based land management scenarios. Sustainability 9(10): 1668. https:// doi.org/10.3390/su9091668

Kastens, B., and J. Newig. 2008. Will participation foster the successful implementation of the water framework directive? The case of agricultural groundwater protection in northwest Germany. Local Environment 13(1):27-41. https://doi. org/10.1080/13549830701581713

Landesamt für Statistik Niedersachsen (LSN). 2018. Anlage 2 zur Pressemitteilung 15/2018. [online] URL: https://www1.nls. niedersachsen.de/statistik/default.asp

Laterra, P., L. Nahuelhual, M. Vallejos, L. Berrouet, E. Arroyo Pérez, L. Enrico, C. Jiménez-Sierra, K. Mejía, P. Meli, A. RincónRuíz, D. Salas, J. Spirić, J. C. Villegas, and C. Villegas-Palacio. 2018. Linking inequalities and ecosystem services in Latin America. Ecosystem Services 36: 100875. https://doi.org/10.1016/ j.ecoser.2018.12.001

Laursen, K., J. Blew, B. Ens, K. Eskildsen, K. Günther, B. Hälterlein, K. Koffijberg, P. Potel, and M. van Roomen. 2009. Migratory birds. Thematic Report No. 19. In H. Marencic and J. de Vlas, editors. Quality status report 2009. WaddenSea Ecosystem No. 25. Common Wadden Sea Secretariat, Trilateral Monitoring and Assessment Group, Wilhelmshaven, Germany.

Levers, C., D. Müller, K. Erb, H. Haberl, M. R. Jepsen, M. J. Metzger, P. Meyfroidt, T. Plieninger, C. Plutzar, J. Stürck, P. H. Verburg, P. J. Verkerk, and T. Kuemmerle. 2018. Archetypical patterns and trajectories of land systems in Europe. Regional Environmental Change 18:715-732. https://doi.org/10.1007/ $\underline{\text { s10113-015-0907-X }}$
Lynham, J., B. S. Halpern, T. Blenckner, T. Essington, J. Estes, M. Hunsicker, C. Kappel, A. K. Salomon, C. Scarborough, K. A. Selkoe, and A. Stier. 2017. Costly stakeholder participation creates inertia in marine ecosystems. Marine Policy 76:122-129. https://doi.org/10.1016/j.marpol.2016.11.011

Mayring, P. 2015. Qualitative Inhaltsanalyse: Grundlagen und Techniken. Beltz Verlag, Weinheim, Germany, and Basel, Switzerland.

MAXQDA. (2018). MAXQDA: Software for qualitative data analysis. VERBI Software - Consult - Sozialforschung GmbH, Berlin, Germany.

Mills, M., J. G. Álvarez-Romero, K. Vance-Borland, P. Cohen, R. L. Pressey, A. M. Guerrero, and H. Ernstson. 2014. Linking regional planning and local action: towards using social network analysis in systematic conservation planning. Biological Conservation 169:6-13. https://doi.org/10.1016/j.biocon.2013.10.015

Moss, B. 2008. The Water Framework Directive: total environment or political compromise? Science of The Total Environment 400(1-3):32-41. https://doi.org/https://doi.org/10.1016/ j.scitotenv.2008.04.029

Moss, T. 2004. The governance of land use in river basins: prospects for overcoming problems of institutional interplay with the EU Water Framework Directive. Land Use Policy 21(1):8594. https://doi.org/10.1016/j.landusepol.2003.10.001

Moss, T. 2012. Spatial fit, from panacea to practice: implementing the EU Water Framework Directive. Ecology and Society 17(3): 2. https://doi.org/10.5751/ES-04821-170302

Nationalpark Wattenmeer. 2014. Biosphärenreservat gemeinsam gestalten. [online] URL: https://www.nationalpark-wattenmeer. de/nds/service/presse/mitteilungen/regionalkonferenz-biosphaerenreservatentwicklungszone-2014

Nationalpark Wattenmeer. 2017. Niedersächsisches Wattenmeer als UNESCO-Biosphärenreservat bestätigt. [online] URL: https:// www.nationalpark-wattenmeer.de/nds/misc/niedersachsisches-wattenmeerals-unesco-biospharenreservat-bestatigt/4405

Newig, J., D. Günther, and C. Pahl-Wostl. 2010. Synapses in the network: learning in governance networks in the context of environmental management. Ecology and Society 15(4): 24. https://doi.org/10.5751/ES-03713-150424

Newig, J., D. Schulz, and N. W. Jager. 2016. Disentangling puzzles of spatial scales and participation in environmental governancethe case of governance re-scaling through the European Water Framework Directive. Environmental Management 58(6):9981014. https://doi.org/10.1007/s00267-016-0753-8

Niedersächsischer Landesbetrieb für Wasserwirtschaft, Küstenund Naturschutz (NLWKN) n.d. Natura 2000. NLWKN, Germany. [online] URL: Niedersächsischer Landesbetrieb für Wasserwirtschaft, Küsten- und Naturschutz (NLWKN) n.d.

Paavola, J., A. Gouldson, and T. Kluvánková-Oravská. 2009. Interplay of actors, scales, frameworks and regimes in the governance of biodiversity. Environmental Policy and Governance 19(3):148-158. https://doi.org/10.1002/eet.505 
Palomo, I., M. R. Felipe-Lucia, E. M. Bennett, B. Martín-López, and U. Pascual. 2016. Chapter 6. Disentangling the pathways and effects of ecosystem service co-production. Pages 245-253 in G. Woodward and D. A. Bohan, editors. Ecosystems services: from biodiversity to society, part 2.. Advances in Ecological Research series, Volume 54. Elsevier Ltd., Amsterdam, The Netherlands. https://doi.org/https://doi.org/10.1016/bs.aecr.2015.09.003

Peçanha Enqvist, J., S. West, V. A. Masterson, L. J. Haider, U. Svedin, and M. Tengö. 2018. Stewardship as a boundary object for sustainability research: linking care, knowledge and agency. Landscape and Urban Planning 179:17-37. https://doi. org/10.1016/j.landurbplan.2018.07.005

Pittman, J., D. Armitage, S. Alexander, D. Campbell, and M. Alleyne. 2015. Governance fit for climate change in a Caribbean coastal-marine context. Marine Policy 51:486-498. https://doi. org/10.1016/j.marpol.2014.08.009

Plieninger, T., and C. Bieling. 2017. The emergence of landscape stewardship in practice, policy and research. Pages 1-18 in C. Bieling and T. Plieninger, editors. The science and practice of landscape stewardship. Cambridge University Press, Cambridge, UK. https://doi.org/10.1017/9781316499016.002

Plieninger, T., T. Kizos, C. Bieling, L. Le Dû-Blayo, M.-A. Budniok, M. Bürgi, C. L. Crumley, G. Girod, P. Howard, J. Kolen, T. Kuemmerle, G. Milcinski, H. Palang, K. Trommler, and P. H. Verburg. 2015. Exploring ecosystem-change and society through a landscape lens: recent progress in European landscape research. Ecology and Society 20(2): 5. https://doi.org/10.5751/ ES-07443-200205

Plummer, R., J. Baird, A. Dzyundzyak, D. Armitage, Ö. Bodin, and L. Schultz. 2017. Is adaptive co-management delivering? Examining relationships between collaboration, learning and outcomes in UNESCO biosphere reserves. Ecological Economics 140:79-88. https://doi.org/10.1016/j.ecolecon.2017.04.028

Prell, C., M. S. Reed, and K. Hubacek. 2011. Social network analysis for stakeholder selection and the links to social learning and adaptive co-management. Pages 95-118 in Ö. Bodin and C. Prell, editors. Social networks and natural resource management: uncovering the social fabric of environmental governance. Cambridge University Press, Cambridge, UK. https://doi. org/10.1017/CBO9780511894985.006

Price, M. F. 2017. The re-territorialisation of biosphere reserves: the case of Wester Ross, Northwest Scotland. Environmental Science and Policy 72:30-40. https://doi.org/10.1016/j.envsci.2017.02.002

R Core Team. 2013. R: a language and environment for statistical computing. R Foundation for Statistical Computing, Vienna, Austria.

Raik, D., A. Wilson, and D. Decker. 2008. Power in natural resources management: an application of theory. Society and Natural Resources 21(8):729-739. https://doi.org/10.1080/08941$\underline{920801905195}$

Raymond, C. M., C. Bieling, N. Fagerholm, B. Martin-Lopez, and T. Plieninger. 2016. The farmer as a landscape steward: comparing local understandings of landscape stewardship, landscape values, and land management actions. Ambio 45 (2):173-184. https://doi.org/10.1007/s13280-015-0694-0
Reed, M. S., A. Graves, N. Dandy, H. Posthumus, K. Hubacek, J. Morris, C. Prell, C. H. Quinn, and L. C. Stringer. 2009. Who's in and why? A typology of stakeholder analysis methods for natural resource management. Journal of Environmental Management 90(5):1933-1949. https://doi.org/10.1016/j. jenvman.2009.01.001

Reed, M. S., S. Vella, E. Challies, J. de Vente, L. Frewer, D. Hohenwallner-Ries, T. Huber, R. K. Neumann, E. A. Oughton, J. Sidoli del Ceno, and H. van Delden. 2017. A theory of participation: what makes stakeholder and public engagement in environmental management work? Restoration Ecology 26(S1): S7-S17. https://doi.org/https://doi.org/10.1111/rec.12541

Reise, K. 2014. Eine Naturgeschichte vom Wattenmeer von Zufällen durchdrungen. Waddenacademie, Leeuwarden, The Netherlands.

Reise, K. 2015. Küstenschutz durch Klimaschutz. Pages 49-62 in K. Reise, editor. Kurswechsel Küste: Was tun, wenn die Nordsee steigt? Wachholtz Verlag, Kiel/Hamburg, Germany.

Reise, K., and O. S. Knottnerus. 2015. Um welche Nordseeküste geht es? Pages 11-35 in K. Reise, editor. Kurswechsel Küste: Was tun, wenn die Nordsee steigt? Wachholtz Verlag, Kiel/ Hamburg, Germany.

Ribot, J. C., and N. L. Peluso. 2003. A theory of access. Rural Sociology 68(2):153-181. https://doi.org/10.1111/j.1549-0831.2003. tb00133.x

Romolini, M., J. M. Grove, and D. H. Locke. 2013. Assessing and comparing relationships between urban environmental stewardship networks and land cover in Baltimore and Seattle. Landscape and Urban Planning 120:190-207. https://doi. org/10.1016/j.landurbplan.2013.08.008

Romolini, M., J. Morgan Grove, C. L. Ventriss, C. J. Koliba, and D. H. Krymkowski. 2016. Toward an understanding of citywide urban environmental governance: an examination of stewardship networks in Baltimore and Seattle. Environmental Management 58(2):254-267. https://doi.org/10.1007/s00267-016-0704-4

Ruoss, E. 2013. Biosphere reserves as model sites for sustainable development. Pages 99-114 in M. Getzner and M. Jungmeier, editors. Protected areas in focus: analysis and evaluation. Volume 4. Verlag Johannes Heyn, Klagenfurt, Austria.

Scharin, H., S. Ericsdotter, M. Elliott, R. K. Turner, S. Niiranen, T. Blenckner, K. Hyytiäinen, L. Ahlvik, H. Ahtiainen, J. Artell, L. Hasselström, T. Söderqvist, and J. Rockström. 2016. Processes for the sustainable stewardship of marine environments. Ecological Economics 128:55-67. https://doi.org/10.1016/j. ecolecon.2016.04.010

Schiffer, E., and J. Hauck. 2010. Net-Map: collecting social network data and facilitating network learning through participatory influence network mapping. Field Methods 22 (3):231-249. https://doi.org/10.1177/1525822X10374798

Schultz, L., C. Folke, H. Österblom, and P. Olsson. 2015. Adaptive governance, ecosystem management, and natural capital. Proceedings of the National Academy of Sciences 112(24):73697374. https://doi.org/10.1073/pnas.1406493112 
Spangenberg, J. H., C. Görg, and J. Settele. 2015. Stakeholder involvement in ESS research and governance: between conceptual ambition and practical experiences - risks, challenges and tested tools. Ecosystem Services16:201-211. https://doi.org/10.1016/j. ecoser.2015.10.006

Stone-Jovicich, S. 2015. Probing the interfaces between the social sciences and social-ecological resilience. Ecology and Society 20 (2): 25. https://doi.org/https://doi.org/10.5751/es-07347-200225

Svendsen, E. S., and L. K. Campbell. 2008. Urban ecological stewardship: understanding the structure, function and management. Cities and the Environment 1(1): 4.

Tengö, M., E. S. Brondizio, T. Elmqvist, P. Malmer, and M. Spierenburg. 2014. Connecting diverse knowledge systems for enhanced ecosystem governance: the multiple evidence base approach. AMBIO 43(5):579-591. https://doi.org/10.1007/ $\underline{\text { s13280-014-0501-3 }}$

Torfing, J. 2005. Governance network theory: towards a second generation. European Political Science 4(3):305-315. https://doi. org/10.1057/palgrave.eps.2210031

Treml, E. A., P. I. J. Fidelman, S. Kininmonth, J. A. Ekstrom, and Ö. Bodin. 2015. Analyzing the (mis)fit between the institutional and ecological networks of the Indo-West Pacific. Global Environmental Change 31:263-271. https://doi.org/10.1016/j. gloenvcha.2015.01.012

UNESCO. (n.d.). Wadden Sea. [online] URL: http://whc.unesco. org/en/list/1314

UNESCO. 1996. Biosphere reserves: the Seville Strategy and the statutory framework of the World Network. UNESCO, Paris, France.

Welchman, J. 2012. A defence of environmental stewardship. Environmental Values 21(3):297-316. https://doi. org/10.3197/096327112X13400390125975

West, S., L. J. Haider, V. A. Masterson, J. Peçanha Enqvist, U. Svedin, and M. Tengö. 2018. Stewardship, care and relational values. Current Opinion in Environmental Sustainability 35:30-38. https://doi.org/10.1016/j.cosust.2018.10.008

Winkler, K. J. 2019. The implementation of the conceptual shift in conservation: pathways of three German UNESCO biosphere reserves. Ecosystems and People 15(1):173-180. https://doi. org/10.1080/26395916.2019.1617351

[1] The German planning law gives people, but also authorized organizations (e.g., certain nature conservation organizations) and public administrations the right to write statements at certain stages during planning processes at all levels (local to federal). Those statements have to be considered and answered, but not necessarily followed. 


\section{Appendix 1}

\section{1) INTERVIEW PARTNERS}

\begin{tabular}{|l|l|}
\hline ABBREVIATION & DESCRIPTION \\
\hline AGR1 & Farmers' association, regional chapter \\
\hline AGR2 & Regional chamber of agriculture \\
\hline AGR3 & Independent agricultural research center \\
\hline CHU & Protestant Lutheran church \\
\hline CON1 & Environmental NGO \\
\hline CON2 & Environmental NGO \\
\hline CON3 & Environmental NGO \\
\hline DEV & EU financed group supporting rural development \\
\hline EADMIN1 & Environmental administration on county level \\
\hline EADMIN2 & $\begin{array}{l}\text { State-level environmental administration in charge of national park, } \\
\text { UNESCO biosphere reserve and UNESCO world heritage site }\end{array}$ \\
\hline MUN & Municipal administration \\
\hline PLAN & Regional planning company \\
\hline RES & University \\
\hline STATE1 & State-level planning authority \\
\hline STATE2 & State-level planning authority with focus on environmental aspects \\
\hline STATE3 & State-level planning authority with focus on coordination of tourism \\
\hline TOU & Regional tourism organization \\
\hline WAT1 & Drinking water supplier \\
\hline WAT2 & Water and draining board \\
\hline WIND & Planning office specialized on wind energy \\
\hline
\end{tabular}




\section{2) CODES}

\section{Sectors}

- Agriculture

- Business

- Citizens

- County

- Federal level

- Energy

- Environmental administration

- EU

- Forest

- Harbor

- Municipality

- National Park/ Biosphere Reserve

- Nature Conservation

- Research

- Resources

- State

- Tourism

- Water

- Wind Energy

Relationships

- Contact

- Nature Conservation - agriculture - tourism - wind

Topics

- Demographic Change

- Hedge banks

- Infrastructure

- Land loss

- Local characteristics

Influence

- Legal

- Political

- Land

- Money 


\section{3) DETAILED DESCRIPTION OF RELATIONSHIP TYPES}

We found two kinds of formalized relationships: 1) member- and ownership and 2) opinions in planning processes. Formalized relationships can involve stakeholders who else would be outside planning and decision-making processes. However, their capabilities and capacities must also be considered, else they cannot contribute to the process.

Member- and ownership is a tight relationship between stakeholder groups. The drinking water company as well as the tourism board are owned by municipalities and counties. The owners influence the activities of the organizations. The regional development group and a private agricultural research center have representatives of other stakeholder groups in their steering committees. Last, the water board and the chamber of agriculture have compulsory membership for people owning land respectively being farmers. Members have less power than owners but can still influence management decisions.

The other type of a formalized relationship is opinion writing for planning processes. German law demands the consultation of relevant public agencies during planning processes including e.g., ENGOs and other public administrations. One ENGO representative said, "I do not want to know how many opinions are written every year about some plans" (CON3). Since many of the local ENGOs work on a voluntary basis, they try "to sometimes coordinate in order to give together an opinion" (CON3).

Our interview partners reported different institutionalized meetings that are not based on a legal requirement but aim at collaboration and information exchange. There are regular meetings within one stakeholder group: for example, a round table for ENGOs with the aim "to develop a common attitude" (CON2). There are meetings of state and non-state stakeholders in the same sector such as ENGOs with the environmental public administration and the National Park administration. Last, there are cross-sectoral meetings. Representatives of tourist organizations, the National Park administration and counties work for example together in a European INTERREG project on sustainable tourism. Another example is a working group between representatives of the local farmers' association, ENGOs and the environmental administration, which serves as a platform for exchange and trust-building. Interview partners involved in these kinds of meetings were positive about them and their outcomes. The 
challenge is to establish and maintain these meetings. Since, they are not required, somebody needs to initiate, organize and host them. However, if they exist they are inclusive allowing different stakeholders to participate.

Many of our interview partners reported on informal relationships within and beyond their sector. They descripted them as partners (WAT2, EADMIN2, DEV), neighbors (WAT2), and friends (DEV). These relationships exist because individual persons want to have and maintain them. They contribute to an information flow between different sectors. Like the institutionalized meetings, they contribute to the understanding of perspectives of others and knowledge about upcoming activities. Representatives of the agricultural (AGR1) and the environmental (CON2) sector described that they received information about upcoming planning processes in advance through their informal relationships with the public administration. Our interviewees did not tell us about regular informal contacts that had a negative connotation. As these relationships are voluntary, it would be surprising to cultivate a negatively connoted relationship. However, if interview partners talked about informal relationships they were not involved in, the descriptions were not as positive and more skeptical. One interviewee (CON3) voiced the concern that "some things happen there [between local politicians and farmers], which we do not get to know" (CON3). Different than the institutionalized meetings, informal relationships are exclusive in that they are not documented and for example for newcomers it can be challenging to join them.

Sporadic relationships with little information exchange also exist. One explanation is often that only one stakeholder has an interest in the relationship. For example, the water board has contact with local industries and businesses when they themselves initiate the contact. Against this, if the water board had contact with the tourism sector, then "they [tourism] want something from us" (WAT2). There is not necessarily frequent contact between all stakeholders within one stakeholder group. Representatives of tourism, agriculture, nature conservation, but also public administration described that there are groups within their own stakeholder group they have sporadic contact with. For the public administration, mainly suitable platforms are missing to exchange with other administrative units. The other stakeholder groups have often conflicting interests and opinions within their sector. 
The last type is no relationship. Sometimes interviewees explicitly expressed that there is no relationship and at other times they did not mention the possibility for a relationship. Looking at the expressed non-relationships, we can differentiate between the intentional and the unintentional not existing relationships. There are intentional non-relationships because attitudes are opposing. For example, a ENGO representative said they do not work with large farms and also not with one other ENGO because it was too extreme in its opinions (CON1). Unintentional not existing relationships also exist. Reasons are that the groups are hard to identify or reach, e.g. wind investors or the EU. Another reason is that there is less of a thematic overlap, e.g. between tourism and the operator of the gas caverns (TOU). To establish relationships would need energy and time of the stakeholders. 


\section{4) DETAILED DESCRIPTION OF INFLUENCE TYPES}

A major part of legal influence on the landscape lies within "the cascade of planning" (WAT). Land use plans determine what can be done in certain areas. The cascade describes that there are different plans from the state, via the county to the municipality level that inform each other. The most concrete plan is at the municipality level. Nature conservation and renewable energy legislation were additionally named as important laws. While nature conservation laws are mostly based on EU policies (e.g., Natura2000), the renewable energy law is a national law. Legal influence is mostly not connected with on-site individuals but with laws and directives and the administration body that implements them.

Court rulings function as control, which can make it necessary to revise decisions or laws. Our interview partners mentioned lawsuits either citizens or ENGOs initiated against wind parks or if they saw nature threatened.

The political sphere of influence is blurry. A law or measure is the final consequence. However, the way to the decision stays for many interview partners cloudy. Public agencies can normally give an opinion on plans and projects. Depending on the process, also ENGOs, other nongovernmental organizations and even citizens can voice their concern or support beside administrative entities such as the water and environmental departments. The members of the municipal council are perceived as powerful because they make decisions with concrete local effects. Different organizations and also individuals influence the decision-making and especially on the local level, stakeholders serve different roles, for example as council member and farmer. Nevertheless, many interview partners recognize the complexity of making land use decisions and nobody raised doubts about the legitimacy of decisions.

Land use shapes the character of the landscape. Non-agrarian interview partners saw land and the power to decide what happens with it as influential. This power is in the hands of landowners and farmers because they make the final land use decision. Members of water boards owning a lot of land have more voting power than those with less land. Interviewees described this as a double power of farmers because they can decide on (1) the land use and (2) the drainage management. However, the representative of the farmers' association 
stressed that there are many demands on the land from e.g. nature conservation or wind energy with the effect that agriculture becomes one of many priorities.

Last financial means influence the landscape development because "if I really want to take some action, I need money for it" (DEV). Subsidies exist for certain land uses and practices especially through the EU Common Agriculture Policy (CAP). A second important subsidy is the national renewable energy act (EEG) that supports the production and installation of renewable energy plants. Until 2017, wind energy in the study area was extremely profitable. Interview partners described that the EFP had extremely economically profited (PLAN). In some areas "you can see hundreds of wind turbines" (CON3) and residents "do not want it anymore" (WAT1). However, an amendment that came into power after the interviews reduces the subsidies in a way that "it will not any longer be that profitable for all. We are happy about this. You must say it like this" (EADMIN).

Other interview partners mentioned subsidies for hedge banks and other traditional land forms in the area (TOU), for certain forms of agriculture such as suckler cow husbandry (AGR1) or for agricultural management that is more environmentally friendly (CON3). Especially the ENGOs representatives described how people in councils are positive towards certain land uses like the exploitation of resources (e.g. sand) and new infrastructure (e.g. high ways) because they see them as economic opportunities. They stressed that there was often not enough money in nature protection to compete against economic uses of the landscape. 


\section{5) INFLUENCE LEVELS}

Perceived influence: Distribution of perceived influence of interview partner self and of another stakeholder group. Last column lists stakeholder group that was perceived as most powerful by interviewee.

\begin{tabular}{|l|l|l|l|}
\hline Interviewee & $\begin{array}{l}\text { Influence } \\
\text { of others }\end{array}$ & $\begin{array}{l}\text { Own } \\
\text { influence }\end{array}$ & Most influence \\
\hline AGR1 & 9 & 1 & municipality \\
\hline AGR2 & 8 & 2 & ENGOs \\
\hline AGR3 & 9 & 1 & state \\
\hline CHU & 10 & 0 & citizens \\
\hline CON1 & 9 & 1 & $\begin{array}{l}\text { agriculture, } \\
\text { business }\end{array}$ \\
\hline CON2 & 10 & 0 & $\begin{array}{l}\text { agriculture, } \\
\text { county }\end{array}$ \\
\hline CON3 & 10 & 1 & agriculture \\
\hline DEV & 9 & 1 & state \\
\hline EADMIN1 & 10 & 0 & municipality \\
\hline EADMIN2 & 9 & 1 & agriculture \\
\hline MUN & 6 & 4 & municipality \\
\hline PLAN & 10 & 0 & $\begin{array}{l}\text { wind energy, } \\
\text { agriculture }\end{array}$ \\
\hline RES & 10 & 0 & $\begin{array}{l}\text { water, } \\
\text { agriculture }\end{array}$ \\
\hline STATE1 & 10 & 0 & agriculture \\
\hline STATE2 & 10 & 0 & business \\
\hline STATE3 & 8 & 2 & tourism \\
\hline TOU & 10 & 0 & National Park \\
\hline WAT1 & 8 & 2 & agriculture \\
\hline WAT2 & 8 & 2 & $\begin{array}{l}\text { water, tourism, } \\
\text { county }\end{array}$ \\
\hline WIND & 10 & 0 & national \\
\hline
\end{tabular}


Appendix 2. -

Please click here to download file 'appendix2.xlsx'. 